\title{
Ageotropic central positional nystagmus in nodular infarction
}

回

Figure Diffusion-weighted axial (A) and sagittal (B) and T2-weighted coronal (C) MRI disclose isolated nodular infarction (arrow). The inset indicates the imaging plane of the corresponding image

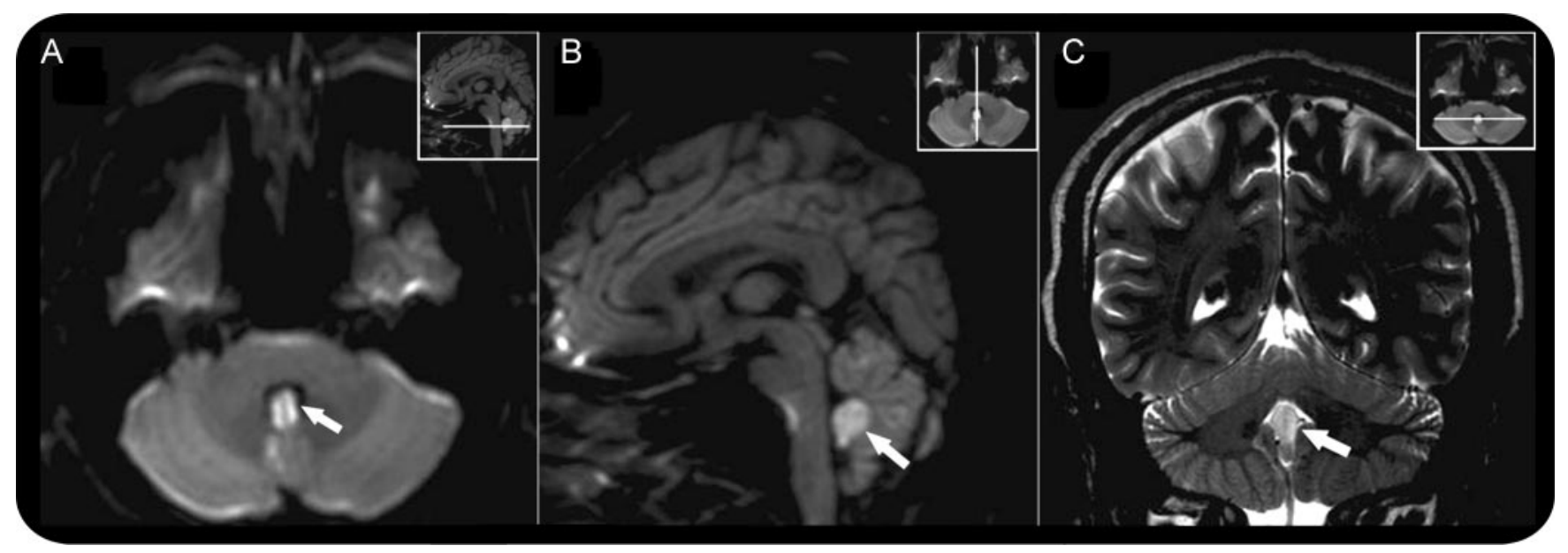

A 36-year-old man with a history of hypertension and atrial fibrillation presented with acute vertigo and imbalance. Neurologic examination revealed ataxic gait and ageotropic positional nystagmus during headturning while supine (video on the Neurology ${ }^{\circledR}$ Web site at www.neurology.org). Other findings of the neurologic examination were normal. MRI showed bilateral nodular infarction (figure).

Central positional nystagmus mostly develops in lesions involving the brainstem or cerebellum. ${ }^{1}$ Isolated nodular infarction may show spontaneous horizontal, periodic alternating, post-head-shaking, and positional nystagmus in addition to imbalance. ${ }^{2}$ Ageotropic central positional nystagmus may be a manifestation of nodular infarction and should be differentiated from benign positional vertigo involving the horizontal semicircular canal. ${ }^{2}$

Jungmoo Nam, MD, Seonhye Kim, MD, Youngeun Huh, MD, and Ji Soo Kim, MD, PhD, Seoul, Republic of Korea Supported by a grant of the Korea Health 21 RéD Project, Ministry of Health \& Welfare, Republic of Korea (A080750).

Disclosure: Dr. Nam, Dr. S. Kim, and Dr. Huh report no disclosures. Dr. J.S. Kim serves as an Associate Editor of the Journal of Korean Neurological Association and on the editorial board of the Journal of Korean Society for Clinical Neurophysiology.

Address correspondence and reprint requests to Dr. Ji Soo Kim, Department of Neurology, Seoul National University College of Medicine, Seoul National University Bundang Hospital, 300 Gumi-dong, Bundang-gu, Seongnam-si, Gyeonggi-do, 463-707, Korea; jisookim@snu.ac.kr

Supplemental data at www.neurology.org
1. Büttner U, Helmchen C, Brandt T. Diagnostic criteria for central versus peripheral positioning nystagmus and vertigo: a review. Acta Otolaryngol 1999;119:1-5.

2. Moon IS, Kim JS, Choi KD, et al. Isolated nodular infarction. Stroke 2009;40:487-491. 


\section{Neurology}

\section{Ageotropic central positional nystagmus in nodular infarction Jungmoo Nam, Seonhye Kim, Youngeun Huh, et al. Neurology 2009;73;1163 \\ DOI 10.1212/WNL.0b013e3181bacfde}

\section{This information is current as of October 5, 2009}

\section{Updated Information \& Services}

Supplementary Material

References

Citations

Subspecialty Collections

Permissions \& Licensing

Reprints including high resolution figures, can be found at: http://n.neurology.org/content/73/14/1163.full

Supplementary material can be found at: http://n.neurology.org/content/suppl/2009/10/04/73.14.1163.DC1

This article cites 2 articles, 1 of which you can access for free at: http://n.neurology.org/content/73/14/1163.full\#ref-list-1

This article has been cited by 1 HighWire-hosted articles: http://n.neurology.org/content/73/14/1163.full\#\#otherarticles

This article, along with others on similar topics, appears in the following collection(s):

\section{Infarction}

http://n.neurology.org/cgi/collection/infarction

Nystagmus

http://n.neurology.org/cgi/collection/nystagmus

Vertigo

http://n.neurology.org/cgi/collection/vertigo

Information about reproducing this article in parts (figures,tables) or in its entirety can be found online at:

http://www.neurology.org/about/about_the_journal\#permissions

Information about ordering reprints can be found online:

http://n.neurology.org/subscribers/advertise

Neurology ${ }^{\circledR}$ is the official journal of the American Academy of Neurology. Published continuously since 1951, it is now a weekly with 48 issues per year. Copyright. All rights reserved. Print ISSN: 0028-3878. Online ISSN: 1526-632X.

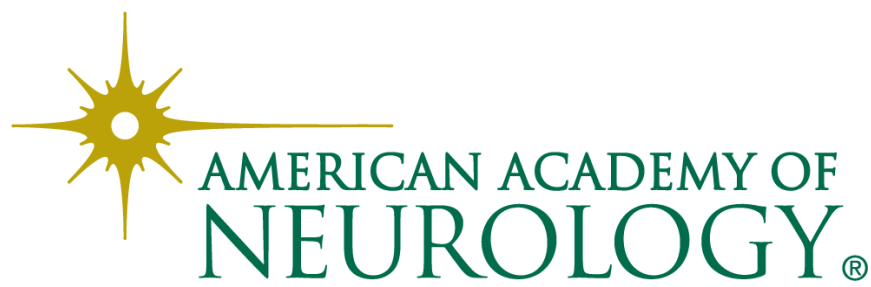

